\title{
Comparative Analysis of Mechanical Properties of WC-Based Cermet Coatings Sprayed by HVOF onto AZ31 Magnesium Alloy Substrates
}

\author{
Ewa Jonda ${ }^{1 *}$, Leszek Łatka² \\ 1 Department of Engineering Materials and Biomaterials, Silesian University of Technology, Konarskiego St. \\ 18a, 44-100 Gliwice, Poland \\ 2 Department of Metal Forming, Welding and Metrology, Faculty of Mechanical Engineering, Wroclaw \\ University of Science and Technology, Łukasiewicza St. 5, 50-371 Wroclaw, Poland \\ * Corresponding author's email: ewa.jonda@polsl.pl
}

\begin{abstract}
Magnesium alloys are very interesting engineering materials due to their very high strength to density ratio (the best among metallic alloys). However, because of low hardness as well as low resistance against erosion, abrasion and corrosion, their applications in the industry is very limited. In order to improve mechanical performances, deposition of hardening coating by thermal spraying was proposed. In this work, the WC-based coatings with different binder $\left(\mathrm{Co}\right.$ or $\mathrm{Ni}$ ) and co-hardening additives $\left(\mathrm{Cr}\right.$ or $\left.\mathrm{Cr}_{3} \mathrm{C}_{2}\right)$ manufactured by high velocity oxy-fuel (HVOF) were studied. These coatings were deposited onto AZ31 magnesium alloy. The crucial problem is obtaining goodadhered coating without damage the substrate, because of relatively low temperature resistance of magnesium alloys (about $300{ }^{\circ} \mathrm{C}$ ). To solve this problem, HVOF method, which is low temperature and high velocity, was proposed. Also an important role plays process parameters (e.g. spray distance, fuel medium, type of nozzle). The goal of the study was to compare three types of cermet coatings manufactured from commercially available powders (WC-Co, WC-Co-Cr and $\mathrm{WC}-\mathrm{Cr}_{3} \mathrm{C}_{2}-\mathrm{Ni}$ ) in terms of their microstructure features, microhardness, instrumented indentation and fracture toughness. Results revealed that selected process parameters made it possible to obtain well-adhered coating with good fulfillment of the surface unevenness of the AZ31 substrate. The most noticeable effect was influence of cobalt matrix on higher hardness (1.4 - 1.6 GPa) and Young modulus (330 - $340 \mathrm{GPa})$ of deposited coatings in compare to the nickel matrix ones (1.2 GPa and $305 \mathrm{GPa}$, respectively). The same trend was observed in case of fracture toughness, c.a. $6.5 \mathrm{MPa} \cdot \mathrm{m}^{1 / 2}$ for Co-matrix and $4.9 \mathrm{MPa} \cdot \mathrm{m}^{1 / 2}$ for Ni-matrix.
\end{abstract}

Keywords: cermet coating, HVOF spraying, magnesium alloy AZ31, microstructure, mechanical properties, indentation test, fracture toughness, microhardness, tungsten carbide

\section{INTRODUCTION}

The intensive development of technology increased the requirements for engineering materials in terms of mechanical properties, corrosive and erosive effects, or resistance to high temperatures [1-4]. Also, for economic reasons, it is important to use coatings which ensure the required product functional properties using possibly cheap materials for element core, from which usually such high-performance properties are not required [5]. High Velocity Oxy Fuel (HVOF) spraying allows to manufacture coatings with special properties, including low oxidation, very low porosity level and high adhesion to the substrate [6-8]. It is particularly important that coatings are free of oxides, which is often required because of exploitative conditions and difficult to achieve with other thermal spray methods (e.g. plasma spraying) [9-11]. Thermal spraying allows a wide choose of coating materials. These materials include metals, alloys, ceramics and composite materials. The substrate on which coating will be sprayed can be metallic and non-metallic. Such combination gives a wide range of possibilities for the choosing and application of fabricated coatings $[12,13]$. In the HVOF process, a gas stream is produced by mixing and igniting oxygen and fuel (gaseous or liquid) in 
combustion chamber. At the same time feedstock material is supplied in the form of a powder into stream. This ensures that gas and material are quickly discharged under high pressure through the nozzle. Due to the working conditions and requirements for coatings, they can have various chemical compositions $[14,15]$. Materials used to improve abrasive properties are most often composite powders that improve substrate wear resistance in many applications: regeneration of machine parts, such as WC-Co, WC-Co-Cr, NiCr-Cr ${ }_{3} \mathrm{C}_{2}$, WC-CrC-Ni. In order to improve abrasive and corrosive properties at elevated temperatures powders $\mathrm{NiCr}-\mathrm{Cr}_{3} \mathrm{C}_{2}$ or NiCr- $\mathrm{Cr}_{3} \mathrm{C}_{2}$, with additional modifications, e.g., $\mathrm{Cr}_{3} \mathrm{C}_{2}$ - $\mathrm{TiC}-\mathrm{NiCr}$, WC-Cr ${ }_{3} \mathrm{C}_{2}-\mathrm{NiCr}$ or $\mathrm{Ni}$ are used [16-19]. Especially WC-based powders are widely used as they are characterized by a very high hardness compared to most cermets, and addition of, for example, $\mathrm{Cr}$ and $\mathrm{Co}$ as binding ingredients improves their strength and provides better coatings adhesion. In the case of sprayed coatings from $\mathrm{Cr}_{3} \mathrm{C}_{2}-\mathrm{NiCr}$ powders, plastic $\mathrm{NiCr}$ phase is the matrix, and the reinforcement is hard $\mathrm{Cr}_{3} \mathrm{C}_{2}$ particles, which are resistant to abrasion [20-24].

The state of the art on the field of HVOF spraying includes deposition on the structural alloy steels, stainless steels, nickel alloys [25-27]. Relatively new and not deep investigated group of the substrate are light metal alloys. A proposed in this paper, AZ31 magnesium alloy with poor mechanical properties could be a good candidate for novel type of substrate for HVOF spraying [28-30].

In this paper, the mechanical properties of the tungsten carbide (WC) based coatings manufactured by HVOF on AZ31 magnesium alloy were examined in terms of their hardness, elastic modulus, fracture toughness, as well as microstructure and porosity level. The influence of the chemical composition on the above mentioned properties was detailed investigated.

\section{MATERIALS AND METHODS}

\section{Feedstock materials}

In this study as a coating material, three commercially available powders: (i) WC-Co-Cr
(Höganäs, Amperit 558.074); (ii) WC-Co (Höganäs, Amperit 518.074) and (iii) $\mathrm{WC}-\mathrm{Cr}_{3} \mathrm{C}_{2}-\mathrm{Ni}$ (Woka 3702-1) were used. The chemical composition of the feedstock powders is presented in the Table 1.

The particle size distribution was in the range 45-15 $\mu \mathrm{m}$ for each one. All powders were agglomerated and sintered. Figure 1 shows the typical scanning electron microscopy (SEM) image (Supra 35, Zeiss, Oberkochen, Germany) of the sprayed powders.

\section{Spraying process}

High Velocity Oxy Fuel (HVOF) method was used to deposit WC-based cermet coatings. The JP 5000 spray system TAFA (Indianapolis, USA) by RESURS (Warszawa, Poland) was used to manufacture coatings. The coatings were deposited on the magnesium alloy AZ31 with $5 \mathrm{~mm}$ in thickness. Before the spraying, the surfaces of the samples were sand - blasted with corundum and ultrasonic cleaned in ethanol. The scheme of spraying and fundamental process parameters are presented in Figure 2.

\section{Microstructure and mechanical properties}

The deposited coatings were analysed using digital optical microscope Keyence VHX6000 (Keyence International). Observations were carried out of the coatings' cross-sections. Samples in as-sprayed conditions have been examined in terms of surface roughness $\left(\mathrm{R}_{\mathrm{a}} \mathrm{pa}\right.$ rameter). It was measured by stylus profilometer (Mahr Surf PS 10), according to the ISO 4288 standard. For each sample ten measurements were carried out. The porosity was assessed on the cross-sections, according to the ASTM E2109-01 standard. The micrographs taken at magnifications of 500x were used. To calculate porosity by image analysis method a software ImageJ was used. The microhardness of sprayed coatings was measured with Vickres indenter under the load of $2.94 \mathrm{~N}$ (HV0.3) using the HV-1000 hardness tester (Sinowon), according to the ISO 4516 standard. For each

Table 1. Chemical composition of the HVOF feedstock powders

\begin{tabular}{|c|c|c|}
\hline Powder & Sample code & Chemical composition, wt. \% \\
\hline WC-Co-Cr & CR1 & $86-10-4$ \\
\hline WC-Co & CR2 & $88-12$ \\
\hline WC-Cr ${ }_{3} \mathrm{C}_{2}-\mathrm{Ni}$ & CR3 & $73-20-7$ \\
\hline
\end{tabular}



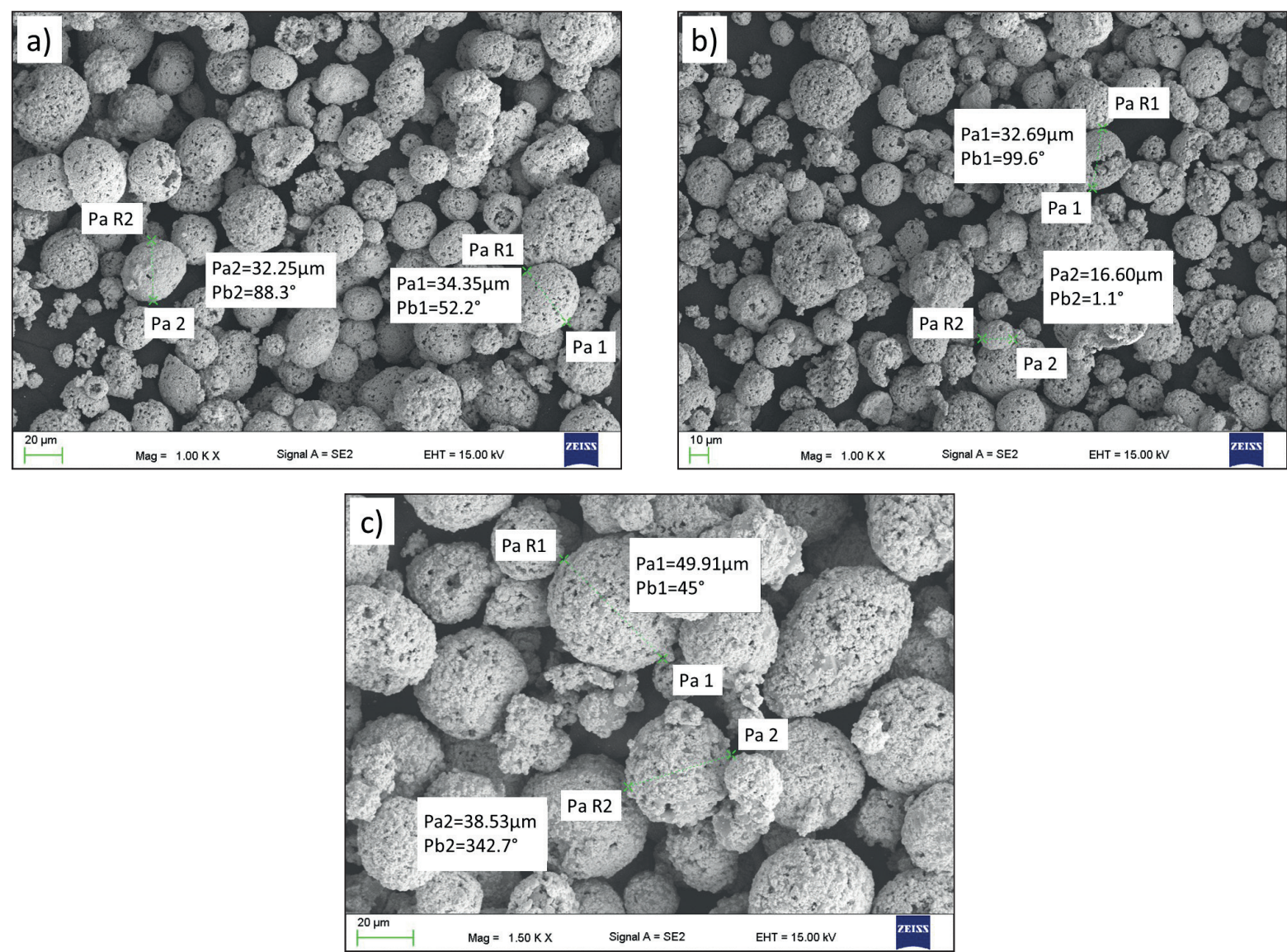

Fig. 1. SEM image of HVOF feedstock powders a) WC-Co-Cr (CR1), b)WC-Co (CR2), c) WC-Cr ${ }_{3} \mathrm{C}_{2}-\mathrm{Ni}$ (CR3)

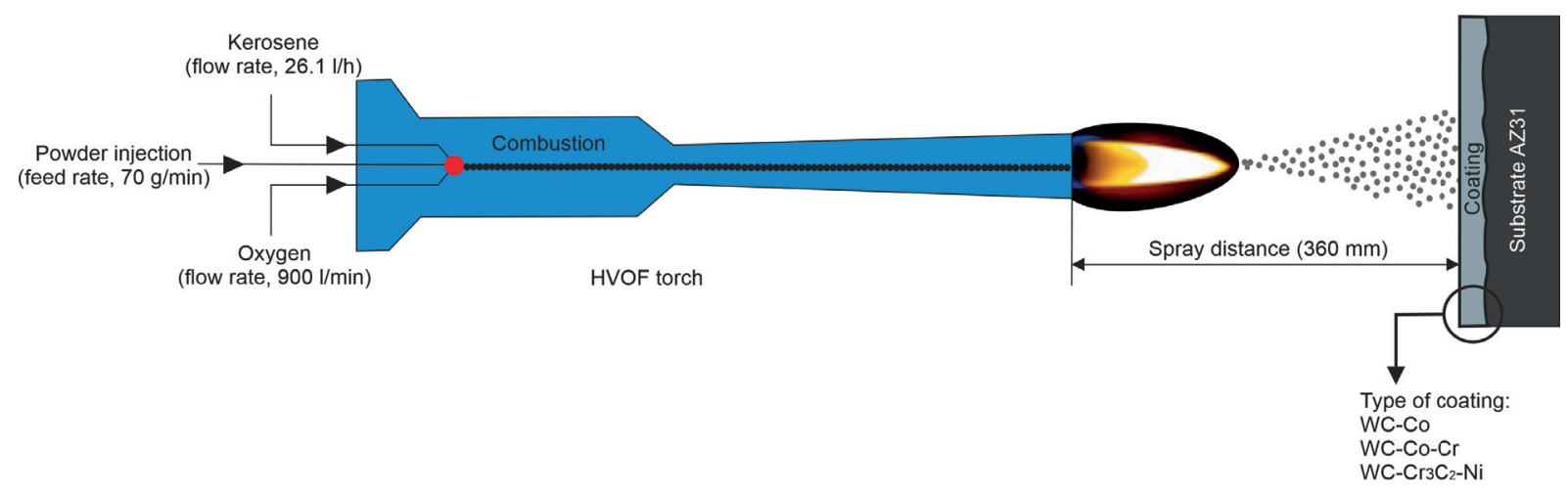

Fig. 2. Scheme of HVOF spraying and fundamental process parameters

coating 10 indentations were made, then average values and standard deviations were calculated. Subsequently, the instrumental indentation tests were carried out using $\mathrm{NHT}^{3}$ nanoindenter (Anton Paar) with Berkovich indenter, according to the ISO 14577-4 standard. Instrumental hardness was determined with the value of maximum load equal to $500 \mathrm{mN}$, according to Oliver-Pharr methodology [31] (Fig. 3).

On the other hand, Young modulus values were calculated from slope of unloading curves for indents with different maximum loads (in present study from 50 up to $500 \mathrm{mN}$, with step equal to $50 \mathrm{mN}$ ). This methodology was originally proposed by Chicot. Fracture toughness was estimated in method based on measurements of cracks length, which occur in the coating material after Vickers indenter penetration. This methodology based on Palmqvist observation. The scheme of cracks and equations are presented in Figure 4 . The value of maximum load was equal to $98.1 \mathrm{~N}(10 \mathrm{kG})$. For each coating seven indents were made, then average values and standard deviations were calculated. 

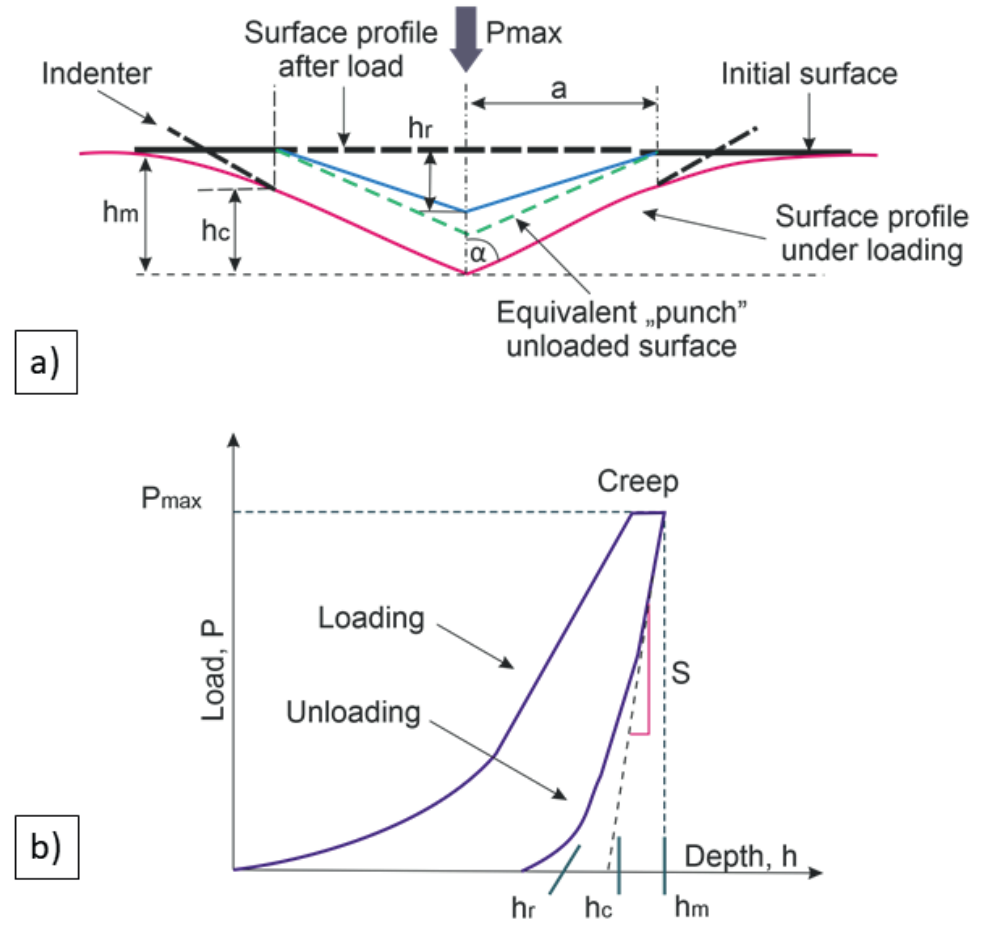

Fig. 3. Scheme on indenter geometry (a) and load-depth curve (b) [32]
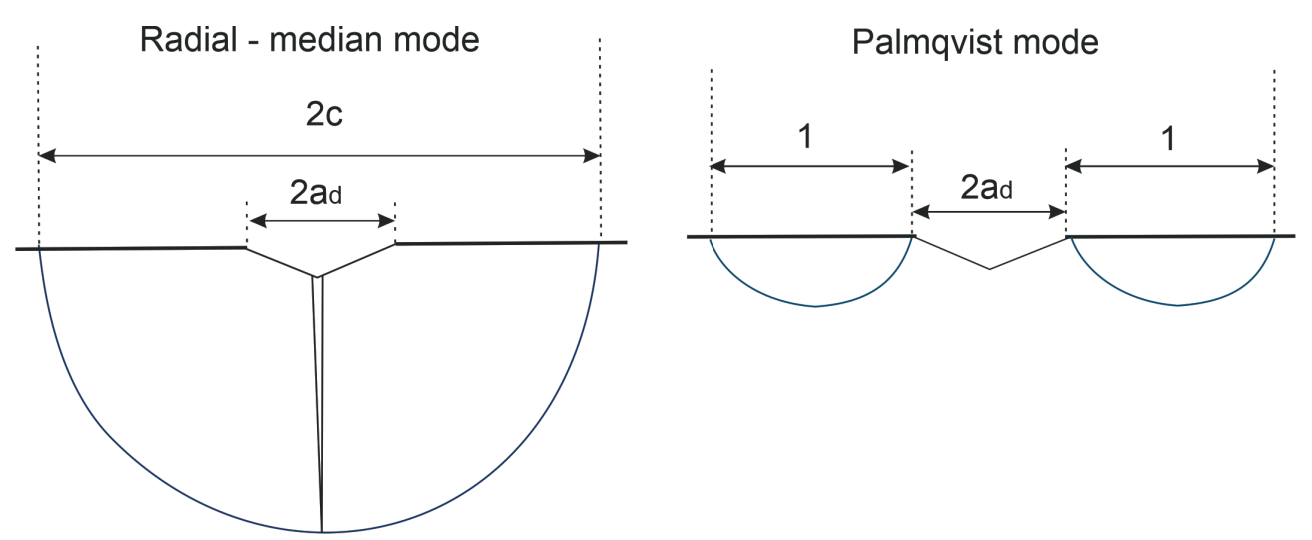

Fig. 4. Scheme of different types of the cracks and presentation of crack [33]

\section{RESULTS AND DISCUSSION}

\section{Coatings microstructure}

The microstructures of the sprayed coatings are presented in Figure 5. It could be seen that all coatings are dense, homogenous and well adhered to the substrate. The average thickness of all coatings varied from about 180 up to $250 \mu \mathrm{m}$. For all samples, at the coatings-substrate interface it could be seen well adhered coating material, which good filled substrate surface irregularities. On the crosssection views a good mechanical interlocking with the substrate $[34,35]$. Such type of structure is a result of the HVOF spraying technology [36].
The surface of the coatings are relatively smooth. The results of the surface roughness as well as coatings porosity are collected in Table 2. The higher surface roughness $\left(\mathrm{R}_{\mathrm{a}}\right)$ was found for $\mathrm{WC}-\mathrm{Cr}_{3} \mathrm{C}_{2}-\mathrm{Ni}$ coating, which probably is related to the two types of hard particles and relatively soft and plastic nickel matrix. The porosity level is comparable with other types of such coatings in literature and it is typical around 1.5 up to 3.0 vol.\% $[37,38]$. Another factor is spraying set-up and HVOF gun. Slight differences in the gun construction could result in the minor discrepancy of coatings microstructure. 

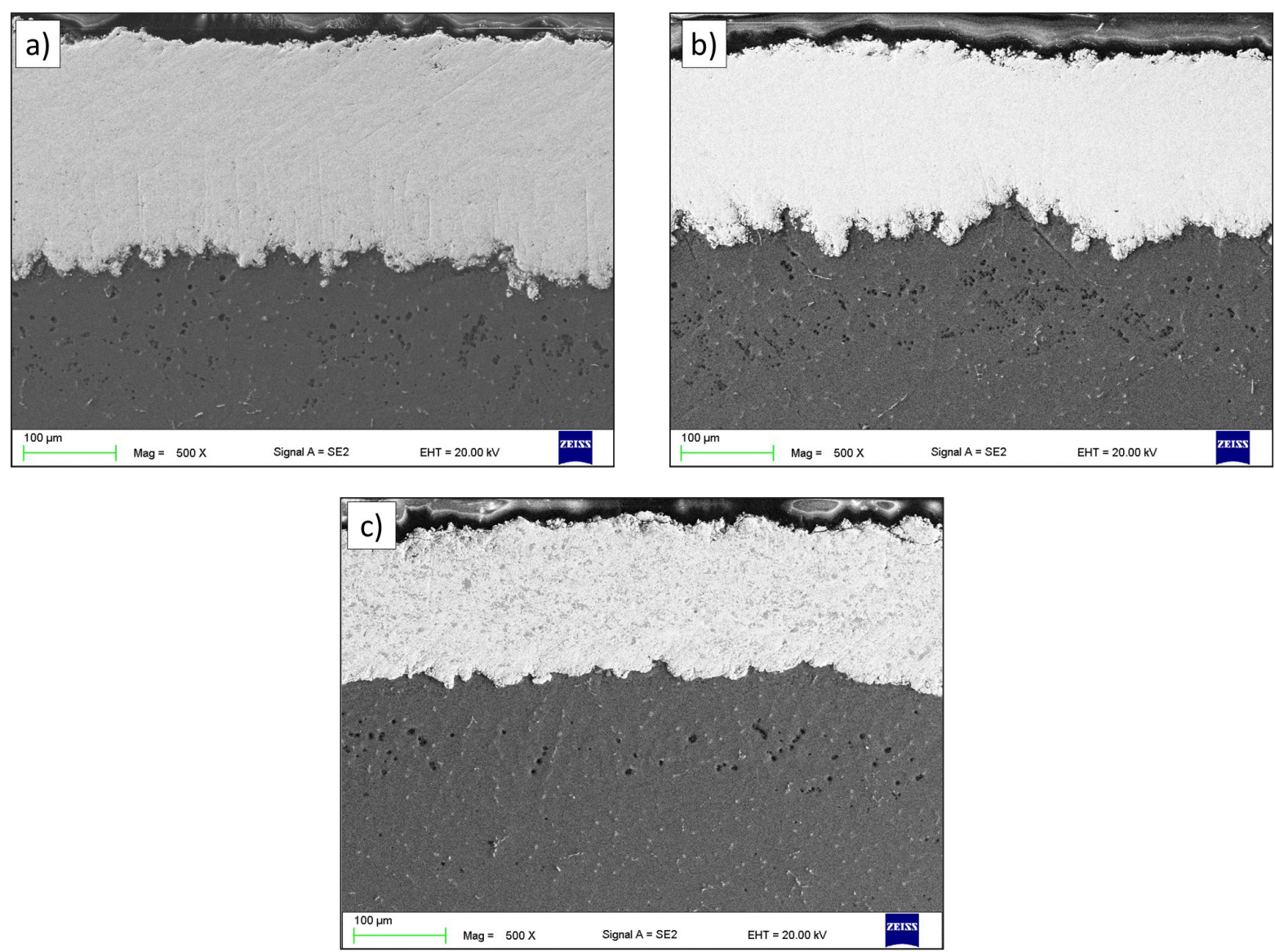

Fig. 5. Cross-sections of manufactured coatings: a) WC-Co-Cr, b) WC-Co, c) $\mathrm{WC}-\mathrm{Cr}_{3} \mathrm{C}_{2}-\mathrm{Ni}$

Table 2. Comparison of the surface roughness and porosity of manufactured coatings

\begin{tabular}{|c|c|c|}
\hline Coating & Surface roughness $\mathrm{R}_{\mathrm{a}}, \mu \mathrm{m}$ & Porosity, vol.\% \\
\hline WC-Co-Cr & $4.5 \pm 0.1$ & $2.9 \pm 0.7$ \\
\hline WC-Co & $4.2 \pm 0.2$ & $2.6 \pm 0.5$ \\
\hline WC-Cr ${ }_{3} \mathrm{C}_{2}-\mathrm{Ni}$ & $5.4 \pm 0.4$ & $1.9 \pm 0.5$ \\
\hline
\end{tabular}

\section{Mechanical properties}

Figure 6 presented the comparison of conventional microhardness (Fig. 6a) and instrumental hardness (Fig. 6b) of deposited coatings. The highest values exhibit WC-Co (1296 HV0.3), whereas the lowest ones are for $\mathrm{WC}_{-}-\mathrm{Cr}_{3} \mathrm{C}_{2}-\mathrm{Ni}(989 \mathrm{HV} 0.3)$ coatings. It may be due to the high content of WC in WC-Co coating and the most compact structure. On the other hand, $\mathrm{WC}-\mathrm{Cr}_{3} \mathrm{C}_{2}$-Ni coating exhibit the lowest porosity and the nickel matrix has lower hardness than cobalt one [36, 39].
Results presented in Table 3 showed, that the Young modulus strongly influences on fracture toughness. In general, for all coatings the cracks length were almost the same dimension. However, the important factors for fracture toughness estimation were also hardness, as well as porosity. Results obtained in current studies are slightly different with some literature data [4042]. It could be explained due to the fact, that these coatings were sprayed with different set-up and slightly differences in the parameters could

Table 3. Comparison of the fracture toughness and Young modulus of manufactured coatings

\begin{tabular}{|c|c|c|}
\hline Coating & Fracture toughness, $\mathrm{MPa} \cdot \mathrm{m}^{1 / 2}$ & Instrumental Young modulus, GPa \\
\hline WC-Co-Cr & $6.42 \pm 0.87$ & 341 \\
\hline WC-Co & $6.65 \pm 0.62$ & 333 \\
\hline WC-Cr ${ }_{3} \mathrm{C}_{2}-\mathrm{Ni}$ & $4.91 \pm 0.57$ & 305 \\
\hline
\end{tabular}



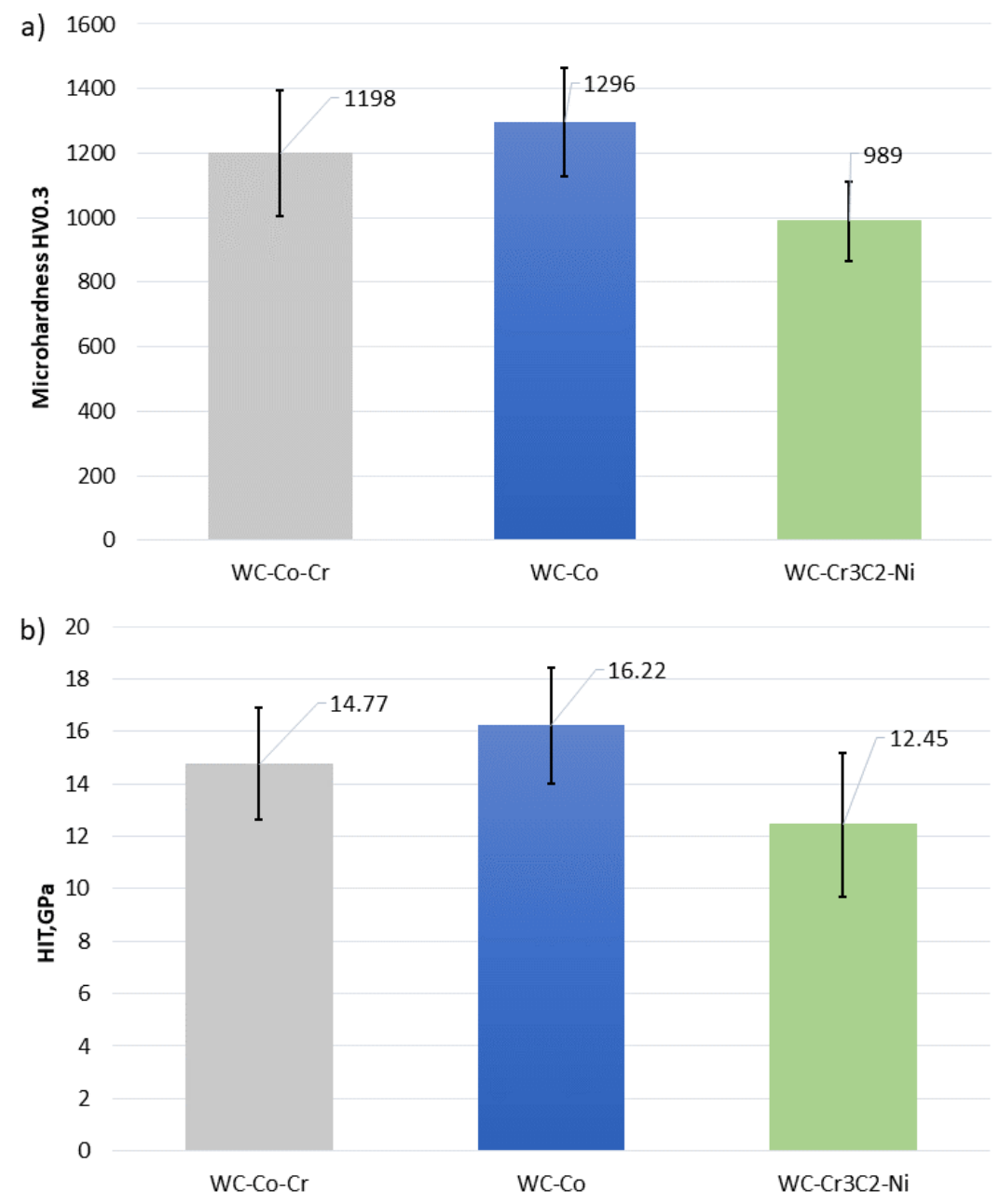

Fig. 6. Comparison of: a) microhardness HV0.3 and b) instrumental hardness HIT

influence on final properties. In case of fracture toughness, insignificantly higher values in present studies (see Table 3), than in literature (from 4.0 up to $\left.5.0 \mathrm{MPa} \cdot \mathrm{m}^{1 / 2}\right)[43,44]$. These differences could be explained by higher porosity level (in range from 2.0 up to 3.0 vol.\%) instead $1.5 \%$ or below, which could stopped cracks propagation.

\section{CONCLUSIONS}

Three WC-based coatings (WC-Co-Cr, WC$\mathrm{Co}$ and $\mathrm{WC}-\mathrm{Cr}_{3} \mathrm{C}_{2}-\mathrm{Ni}$ ) were deposited by HVOF method on AZ31 magnesium alloy. The following findings can be summarized:

1. All coatings have been successfully deposited, the coating-substrate interface was clear, without discontinuities and with good mechanical interlocking between coating and substrate.

2. Microscopic observation revealed dense structure (porosity level below 3.0 vol.\% and smooth surface $\left(\mathrm{R}_{\mathrm{a}}\right.$ below $\left.5.5 \mu \mathrm{m}\right)$ of assprayed samples.
3. Microhardness and instrumental hardness measurements showed the same tendency (WC-Co $>$ WC-Co-Cr $>$ WC-Cr ${ }_{3} \mathrm{C}_{2}-\mathrm{Ni}$ ). Moreover, they confirmed that coatings based on cobalt matrix exhibit higher microhardness (1198 HV0.3 for WC-Co$\mathrm{Cr}$ and $1296 \mathrm{HV} 0.3$ for WC-Co) than ones based on nickel matrix (989 HV0.3 for $\mathrm{WC}-\mathrm{Cr}_{3} \mathrm{C}_{2}-\mathrm{Ni}$ ).

4. Fracture toughness value was the highest for WC-Co coating $\left(6.65 \mathrm{MPa} \cdot \mathrm{m}^{1 / 2}\right)$, whereas the highest value of instrumental Young modulus was find for WC-Co-Cr coating (341 GPa).

5. Based on the above results, the most promising candidate for further dry sliding, erosion and cavitation resistance coating could be WC$\mathrm{Co}-\mathrm{Cr}$ one. It is characterized by considerable hardness, relatively good fracture toughness and high value of elastic modulus.

\section{Acknowledgement}

These investigations were financed by the Ministry of Science and Higher Education of Poland, Grant DEC - 2019/03/X/ST5/00830. 


\section{REFERENCES}

1. Pawłowski L. The Science and Engineering of Thermal Spray Coatings. Second Edition; 2008.

2. Geaman V., Pop M.A., Motoc D.L., Radomir I. Tribological properties of thermal spray coatings. European Scientific Journal. 2014; 3: 154-159.

3. Ozkan D., Yilmaz M.A., Szala M., Turkuz C., Chocyk D., Tunc C., Goz O., Walczak M., Pasierbiewicz K., Yagci M.B. Effects of ceramic-based CrN, TiN, and AlCrN interlayers on wear and friction behaviors of AlTiSiN+TiSiN PVD coatings. Ceramic International. 2021; (In press).

4. Fauchais P., Heberlein J.V.R., Boulos M.I. Thermal Spray Fundamentals, From Powder to Part, Springer; 2014.

5. Walczak M., Pasierbiewicz K., Szala M., Adhesion and mechanical properties of TiAlN and Altin magnetron sputtered coatings deposited on the DMSL titanium alloy substrate. Acta Physica Polonica A. 2019; 136(2): 294-298.

6. Sobolev V.V., Guilemany J.M. and Nutting J. High Velocity Oxy-Fuel Spraying. Theory, StructureProperty Relationships and Applications; 2004.

7. Formanek B., Szymański K., Kuczowitz B. Coatings resistant to corrosion and abrasive wear obtained by thermal spraying methods. Corrosion protection. 2010; 53(3):164-168.

8. Oksa M., Turunen E., Suhonen T., Varis T. and Hannula S.-P. Optimization and Characterization of High Velocity Oxy-fuel Sprayed Coatings: Techniques, Materials, and Applications. Coatings. 2011; 1, 17-52.

9. Karaoglanli A.C., Oge M., Doleker K.M., Hotamis M. Comparison of tribological properties of HVOF sprayed coatings with different composition. Surface \& Coatings Technology. 2017; 318(25): 299-308.

10. Żórawski W. Properties of plasma and HVOF sprayed Coatings. Tribologia. 2010; 6: 319-327.

11. Łatka L., Pawłowski L., Winnicki M., Sokołowski P., Małachowska A., Kozerski S., Review of functionally graded thermal sprayed coatings. Applied Sciences. 2020; 10(15): 5153.

12. Nahvi S.M., Jafari M. Microstructural and mechanical properties of advanced HVOF-sprayed WC-based cermet Coatings. Surface and Coatings Technology. 2016; 286: 95-102.

13. Sendrowski C., Bojar Z., Szymański K., Formanek B. The structure and properties investigations of multilayer $\mathrm{NiAl} / \mathrm{FeAl}$ and $\mathrm{NiCr} / \mathrm{FeAl}$ Coatings obtained by HVOF spraying. Material Engineering. 2008; 6:611-614.

14. Wang H., Qiu Q., Gee M., Hou Ch., Liu X., Song $\mathrm{X}$. Wear resistance enhancement of HVOF-sprayed WC-Co coating by complete densification of start- ing powder. Materials and design. 2020; 191: 108586 .

15. Myalska H., Lusvarghi L., Bolelli G., Sassatelli P., Moskal G. Tribological behavior of WC-Co HVAF-sprayed composite coatings modified by nano-sized TiC addition. Surface and Coatings Technology. 2019; 371: 401-416.

16. Yao H.L., Yang Ch., Yi D.-L., Zhang M.-X., Wang H.-T., Chen Q.-Y., Bai X.-B., Ji G.-Ch. Microstructure and mechanical property of high velocity oxyfuel sprayed WC-Cr $\mathrm{C}_{2}-\mathrm{Ni}$ Coatings. Surface and Coatings Technology. 2020; 397: 126010.

17. Bhosale G.D, Prabhu T.R., Walmik S.R., Manik A.P., Rukhande W.S. High temperature solid particle erosion behaviour of SS 316L and thermal sprayed WC-Cr $\mathrm{C}_{2}-\mathrm{Ni}$ Coatings. Wear. 2020; 462463:203520.

18. Mayrhofer E., Janka L., Mayr W. P., Norpoth J., Ripoll M. R., Gröschl M. Cracking resistance of $\mathrm{Cr}_{3} \mathrm{C}_{2}-\mathrm{NiCr}$ and $\mathrm{WC}-\mathrm{Cr}_{3} \mathrm{C}_{2}-\mathrm{Ni}$ thermally sprayed coatings under tensile bending stress. Surface \& Coatings Technology. 2015; 281: 169-175.

19. Ishikawa Y., Kuroda S., Kawakita J., Sakamoto Y., Takaya M. Sliding wear properties of HVOF sprayed WC- $-20 \% \mathrm{Cr}_{3} \mathrm{C}_{2}-7 \% \mathrm{Ni}$ cermet coatings. Surface \& Coatings Technology. 2007; 201: 4718-4727.

20. García-Rodríguez S., López A. J., Bonache Victoria., Torres B. and Rams J. Fabrication, Wear, and Corrosion Resistance of HVOF Sprayed WC-12Co on ZE41 Magnesium Alloy. Coatings. 2020; 10 (502): doi:10.3390/coatings10050502.

21. Lee Seoung. S. Wear Behaviors of WC-CoCr and WC-CrC-Ni Coatings Sprayed by HVOF. Journal of the Korea Academia-Industrial cooperation Society. 2020; 21(6): 204-211.

22. Tillmann W., Hagen L., Schaak C., Liß J., Schaper M., Hoyer K.-P., Aydinöz M. E., Garthe K.-U.Adhesion of HVOF-Sprayed WC-Co Coatings on 316L Substrates Processed by SLM. Journal of Thermal Spraying Technology. 2020; 29: 1396-1409.

23. Hong S., Wu Y. P., Gao W.W., Wang B., Guo W.M. and Lin J. R. Microstructural characterisation and microhardness distribution of HVOF sprayed WC$10 \mathrm{Co}-4 \mathrm{Cr}$ coating. Surface Engineering. 2014; 30(1): 53-58.

24. Méndez-Medrano K.O., Martínez-González C. J., Alvarado-Hernández F., Jiménez O., BaltazarHernández V.H, Ruiz-Luna H. Microstructure and Properties Characterization of WC-Co-Cr Thermal Spray Coatings. Journal of Minerals and Materials Characterization and Engineering. 2018; 6: 482-497.

25. Mazaheri Y., Jalilvand M.M., Heidarpour A., Jahani A.R. Tribological behavior of AZ31/ZrO2 surface nanocomposites developed by friction stir processing. Tribology International.2020; 143: 106062 
26. Fouad, Y.; El Batanouny, M. Effect of surface treatment on wear behavior of magnesium alloy AZ31. Alexandria Engineering Journal. 2011; 50: 19-22.

27. Chang L.L., Wang Y.N., Zhao X., Huang J.C., Microstructure and mechanical properties in an AZ31 magnesium alloy sheet fabricated by asymmetric hot extrusion. Materals Science Engineering A. 2008; 496: 512-516

28. Myalska H., Dybowski B., Moskal G. WC-Co coatings and sinters modified with nano-sized TiC microstructure - quantitative evaluation. Advances in Science and Technology Research Journal. 2017; 11(1): 220-231.

29. Szala M., Walczak M., Łatka L., Gancarczyk K., Özkan D. Cavitation erosion and sliding wear of MCrAlY and NiCrMo coatings deposited by HVOF thermal spraying. advances in materials science. 2020; 20/2(64): 26-38.

30. Abbas M., Smith G. M., Munroe P. R. Microstructural Characterization of HVOF-Sprayed Nion Polished and Oxidized Stainless Steel Substrates. Journal of Thermal Spraying Technology. 2020; 29: 1093-1110.

31. Oliver W.C. and Pharr G.M. An Improved Technique for Determining Hardness and Elastic Modulus Using Load and Displacement Sensing Indentation Experiments. Journal Materials Research. 1992; 7(06): 1564-1583.

32. Chicot D. and Tricoteaux A. Mechanical Properties of Ceramic by Indentation: Principle and Applications, Ceramic Materials. Wilfried Wunderlich (Ed.); 2010, InTech.

33. Houdková Š., Kašparová M. Experimental study of indentation fracture toughness in HVOF sprayed hardmetal coatings. Engineering Fracture Mechanics. 2013; 110: 468-476.

34. Luiz L.A., de Andrade J., Pesqueira C.M. et al. Corrosion Behavior and Galvanic Corrosion Resistance of WC and $\mathrm{Cr}_{3} \mathrm{C}_{2}$ Cermet Coatings in Madeira River Water. Jornal of Thermal Spraying Technology.2021; 30: 205-221.

35. Song B., Murray J.W., Wellman R.G., Pala Z., Hussain T. Dry sliding wear behaviour of HVOF thermal sprayed $\mathrm{WC}-\mathrm{Co}-\mathrm{Cr}$ and $\mathrm{WC}-\mathrm{CrxCy}-\mathrm{Ni}$ coat- ings. Wear. 2020; 442-443.

36. Qiao L., Wu Y., Hong S., Long W. ,Cheng J. Wet abrasive wear behavior of WC-based cermet coatings prepared by HVOF spraying. Ceramic International. 2021; 47: 1829-1836.

37. Zhan S.-H., Cho T.-Y., Yoon J.-H., Li M.-X., Shum P.W., Kwon S.-C. Investigation on microstructure, surface properties and anti-wear performance of HVOF sprayed WC-Cr-Ni coatings modified by laser heat treatment. Material Science Engineering B. 2009; 162: 127-134.

38. Sidhu H.S., Sidhu B.S., Prakash S. Mechanical and microstructural properties of HVOF sprayed WC-Co and $\mathrm{Cr}_{3} \mathrm{C}_{2}-\mathrm{NiCr}$ coatings on the boiler tube steels using LPG as the fuel gas. Journal Materials Processing Technology. 2006; 171: 77-82.

39. Houdkova S., Blahova O., Zahalka F., Kasparova M. The instrumented indentation study of HVOFsprayed hardmetal coatings. Journal of Thermal Spray Technology. 2012; 21(1): 77-85.

40. Bolelli G., Berger L.-M., Bonetti M., Lusvarghi L. Comparative study of the dry sliding wear behaviour of HVOF-sprayed WC-(W,Cr)2C-Ni and WC-CoCr hard metal coatings. Wear. 2014; (309): 96-111.

41. Culha O., Toparli M., Celik E., Aksoy T., Soykan H.S. Indentation size effect on mechanical properties of HVOF sprayed WC based cermet coatings for a roller cylinder. Surface and Coatings Technology. 2009; (203): 2052-2057.

42. Matikainena V., Peregrina S.R., Ojala N., Koivuluoto H., Schubert J., Houdková Š., Vuoristo P. Erosion wear performance of $\mathrm{WC}-10 \mathrm{Co} 4 \mathrm{Cr}$ and $\mathrm{Cr}_{3} \mathrm{C}_{2}-25 \mathrm{NiCr}$ coatings sprayed with high-velocity thermal spray processes. Surface Coatings \& Technology. 2019; 370: 196-212.

43. Vashishtha N., Khatirkar R.K., Sapate S.G. Tribological behaviour of HVOF sprayed WC-12Co, WC-10Co-4Cr and $\mathrm{Cr}_{3} \mathrm{C}_{2}-25 \mathrm{NiCr}$ coatings. Tribology International. 2017; (105): 55-68.

44. Yao H.-L., Yang C., Yi D.-L., Zhang M.-X., Wang H.-T., Chen Q.-Y., Bai X.-B., Ji G.-C. Microstructure and mechanical property of high velocity oxyfuel sprayed $\mathrm{WC}-\mathrm{Cr}_{3} \mathrm{C}_{2}-\mathrm{Ni}$ coatings. Surface Coatings \& Technology. 2020; 397: 126010. 